\title{
Still Controversial: Early Detection and Screening for Breast Cancer in Brazil, 1950-2010s
}

\author{
LUIZ ANTONIO DA SILVA TEIXEIRA ${ }^{1 *}$ and LUIZ ALVES ARAÚJO NETO ${ }^{2 * *}$ \\ ${ }^{1}$ Oswaldo Cruz Foundation (FIOCRUZ), Rio de Janeiro, Brazil \\ ${ }^{2}$ National Cancer Institute Jose Alencar Gomes da Silva (INCA), Rio de Janeiro, Brazil
}

\begin{abstract}
Mammographic screening for breast cancer is a widely used public health approach, but is constantly a subject of controversy. Medical and historical research on this topic has been mainly conducted in Western Europe and North America. In Brazil, screening mammography has been an open topic of discussion and a challenge for health care and public health since the 1970s. Effectively, Brazilian public health agencies never implemented a nationwide population-based screening programme for breast cancer, despite the pressures of many specific groups such as advocacy associations and the implementation of local programmes. This article examines the complex process of incorporating mammography as a diagnostic tool and the debates towards implementing screening programmes in Brazil. We argue that debates about screening for breast malignancies, especially those conducted in the late twentieth and early twenty-first centuries, took place in a context of change and uncertainty in the Brazilian health field. These discussions were strongly affected both by tensions between the public and the private health care sectors during the formative period of a new Brazilian health system, and by the growing role of civil society actors. Our study investigates these tensions and their consequences. We use several medical sources that discussed the topic in Brazil, mainly specialised leading oncology journals published between 1950 and 2017, medical congress reports for the same period, books and theses, institutional documents and oral testimonies of health professionals, patients and associations collected in the framework of the 'The History of Cancer' project from the Oswaldo Cruz Foundation and Brazilian National Cancer Institute.
\end{abstract}

Keywords: Breast Cancer, Screening, Early Detection, Brazil, Public Health, Health Care

\author{
* Praia do Flamengo Avenue, 82, apt. 805/ Rio de Janeiro, Brazil. \\ Email address for correspondence: luiztei3@gmail.com \\ ***Present affiliation: Oswaldo Cruz Foundation (FIOCRUZ), Rio de Janeiro, Brazil
}

We would like to thank Andreza Nakano and Ilana Löwy for their insightful readings and comments on this paper. This research is funded by the Foundation of Support to Research of the State of Rio de Janeiro (FAPERJ) through the Cientista do Nosso Estado grant [E-26/202.805/2018 (238541)] and the Humanidades grant [E-26/210.115/2016(215960)]. 


\section{Introduction}

In 2008, Brazilian National Congress promulgated Law No. 11664, which ensured a 'mammographic examination for all women from the age of forty onwards'. Mammography is a widely distributed public health technique for both diagnosing and screening for breast cancer. However, it is constantly the subject of debates. ${ }^{2}$ Controversies about this screening technology are usually focused on its cost-efficacy, and its harmbenefit ratio. ${ }^{3}$ Mammography's advocates claim that numerous clinical trials have shown that population-based screening reduces mortality from breast tumours. ${ }^{4}$ Its opponents point to risks of overdiagnosis, overtreatment and 'overselling' of mammography benefits. $^{5}$

Both historical and medical researches on this topic have been mainly conducted in Western Europe and North America. In Brazil, screening mammography has been an open topic of discussion and a challenge for health care and public health since the 1970s. Effectively, Brazilian public health agencies never implemented a population-based nationwide screening programme for breast cancer, despite the pressures of many specific groups, such as advocacy associations. In fact, mammography has been incorporated into clinical medicine as a diagnostic tool aimed at early detection and opportunistic screening - in the private sector. The understanding of how this framework was established in Brazil offers a unique opportunity to learn more about cancer control and the relationship between public and private health care sectors in this country.

This article examines the complex process of incorporating mammography as a diagnostic tool and the debates towards implementing screening programmes in Brazil. We argue that debates about screening for breast malignancies, especially those debates conducted in the late twentieth and early twenty first centuries, took place in a context of change and uncertainty in the Brazilian health arena. These discussions were strongly affected both by tensions between the public and the private health care sectors during the formative period of a new Brazilian health system and by the growing role of civil society actors. Our study investigates these tensions and some of their consequences.

Until the mid-twentieth century, treatment of breast cancer - and other tumours - in Brazil was mainly surgical, although a few leading institutions introduced radiotherapy and radium therapy after the 1940 s. $^{6}$ Breast cancer patients were treated either in public hospitals or those funded by philanthropic organisations; some of the latter specialised in cancer therapy. ${ }^{7}$ Physicians from the National Cancer Service (SNC) claimed that the cause of breast cancer was chronic inflammation and argued that it should be diagnosed

\footnotetext{
${ }^{1}$ Brasil, Ministério da Saúde, Lei no 11.664, de 29 de abril de 2008. Dispõe sobre a efetivação de ações de saúde que assegurem a prevenção, a detecção, o tratamento e o seguimento dos cânceres do colo uterino e de mama, no âmbito do Sistema Único de Saúde - SUS. Available at: www.planalto.gov.br/legislacao. Accessed: 15 September 2017.

2 Robert Aronowitz, 'To Screen or Not to Screen: What is the Question?', Journal of General Internal Medicine, 10 (1995), 295-7.

${ }^{3}$ Ibid.

${ }^{4}$ P. Gøtzsche and K. Jorgensen, 'Screening for Breast Cancer with Mammography', Cochrane Database of Systematic Reviews, 2013, 6 (2013), art. n. CD001877.pub5.

${ }^{5}$ N. Biller Adorno and P. Jüni, 'Abolishing Mammography Screening Programs? A View from the Swiss Medical Board', New England Medical Journal, 370, 21 (2014), 1965-7; G. Gigerenzer et al., 'Public Knowledge of Benefits of Breast and Prostate Cancer Screening in Europe', JNCI, 101, 17 (2009), 1216-20.

${ }^{6}$ Luiz Teixeira and Cristina Fonseca, De doença desconhecida a problema de saúde pública: o INCA e o controle do cancer no Brasil (Rio de Janeiro: Ministério da Saúde, 2007).

${ }^{7}$ Ibid.
} 
as early as possible to limit the need for extensive surgeries. They advised women to be alert to their bodies and consult a specialist whenever they noticed unusual changes or symptoms. ${ }^{8}$ An increase in the incidence of breast cancer in Brazil was attributed to the urbanisation and modernisation of the country's wealthiest areas, and the ageing of the female population. ${ }^{9}$

The rapid development of hospital medicine in Brazil from the 1940s onwards, due to the expansion of social security and public health care services for certain categories of (urban) workers, favoured the dissemination of mastectomy. ${ }^{10}$ In parallel, educational campaigns conducted by the SNC and regional associations for cancer control urged women to seek medical help to increase the early detection of malignant tumours. ${ }^{11} \mathrm{~A}$ timely discovery of a breast tumour was seen as part of women's responsibility. At the same time, in the 1940s and 1950s state interventions in the diagnosis and treatment of breast malignancies had a very limited scope and left the vast majority of women who needed treatment without coverage. ${ }^{12}$

After World War II, screening for numerous diseases, including malignant tumours, had become an increasingly popular medical practice. ${ }^{13}$ In Brazil, as in Western Europe and North America, a perceived success of cervical cancer prevention campaigns based on the detection of early lesions served as a model for breast cancer screening. ${ }^{14}$ In the 1970 s and 80s, screening was favoured by the development of new medical imagery technologies. The advent of these technologies intensified professional and lay discussion about screening for breast malignancies in Brazil. These discussions were further amplified in the 1990s by mobilisations around women's health and the transformation of public health structures by the creation of the Brazilian unified National Health System (SUS).

Until the 1980s, the Brazilian health system was divided into three dimensions: public health, which was responsible for promoting health education and prevention campaigns as well as dealing with specific disease-oriented strategies; social security, which was directed at groups of urban workers and related to the development of hospital medicine in Brazil; and, finally, philanthropy, which funded chronic disease and terminal patients' care. ${ }^{15}$ In the mid-1980s, a group of researchers and public health professionals articulated the creation of a new health system, in a movement known as 'The Sanitary Reform'. ${ }^{16}$ This new health system was based on the constitutional right to health, which

\footnotetext{
${ }^{8}$ Luiz Teixeira and Carla Gruzman, 'Os Materiais Educativos para a Prevenção do Câncer no Brasil: da perspectiva histórica à dimensão discursiva', in L.M. Bertucci, A. Mota and L.B. Schraiber (eds), Saúde e Educação: um encontro plural (Rio de Janeiro: Editora Fiocruz, 2017), 131-63.

9 Thayane Oliveira, 'Você finge não ver e isso dá cancer': controle do cancer de mama no Ceará, 1960-1980 (unpublished dissertation: Oswaldo Cruz Foundation, 2017).

${ }^{10}$ Marco Porto, Luiz Teixeira and Ronaldo Silva, 'Aspetos históricos do controle de cancer de mama no Brasil', Revista Brasileira de Cancerologia, 59, 3 (2013), 331-9.

11 Ibid.

12 Another rather important problem was the difficulty of physicians to diagnose a breast tumour. According to leading physicians of the National Cancer Institute (NCI), such as the surgeon and gynaecologist Alberto Coutinho, most doctors didn't even know how to identify a lump in a clinical examination. See Alberto Coutinho, 'Educação profissional do médico na luta contra o câncer', Arquivos de Oncologia., V, 1 (1963), 15-17.

13 David Armstrong, 'Screening: Mapping Medicine's Temporal Spaces', Sociology of Health \& Illness, 34, 2 (2012), 177-93.

14 lana Löwy, Preventive Strikes: Women, Cancer and Prophylactic Surgery (Baltimore: John Hopkins, 2010).

${ }^{15}$ Sarah Escorel and Luiz Teixeira, 'História das políticas de saúde no Brasil de 1822 a 1963: do império ao desenvolvimentismo populista', in Ligia Giavonella et al. (ed.), Políticas e Sistemas de Saúde no Brasil (Rio de Janeiro: Editora Fiocruz, 2008).

${ }^{16}$ Luiz Teixeira and Carlos Henrique Paiva, 'Saúde e reforma sanitária entre o autoritarismo e a democracia', in
} 
defined health care as a government obligation, the decentralisation of health services administration and the broadening of health promotion and prevention. At that time, new actors, including medical societies and patients' associations, joined debates about mammographic screening.

Nowadays, breast cancer is, after non-melanoma skin cancer, the most prevalent malignancy among Brazilian women. ${ }^{17}$ Despite decades of medical campaigns and public policies, mortality from breast cancer in Brazil remains high when compared to ratios observed in other developed countries, mainly because breast cancer is frequently diagnosed at an advanced stage. ${ }^{18}$ Experts agree that the main strategies for breast cancer control are primary prevention (identification and correction of avoidable risk factors), secondary prevention (early detection and treatment) and tertiary prevention (rehabilitation and palliative care). Brazilian public health and medical experts also acknowledge that secondary prevention strategies are the only measures that promote reduction in mortality rates and, for this reason, they have received more attention by the national health system. ${ }^{19}$ However, the adequacy of mammographic screening in Brazil and the choice of screening models for implementation are still controversial. ${ }^{20}$

Screening is a recurrent subject in medical history, being approached on different analytical perspectives. Three main strands can be indicated: health management by insurance companies; technological development; and surveillance medicine. Regarding the first point, George Weisz, ${ }^{21}$ argues that Irving Fisher' National Vitality Report, articulated with insurance companies' concerns about their losses due to disabilities, was fundamental for the Commission of Chronic Illness propositions of multiphasic screening programmes in the US.

Another interpretative path was proposed by sociologist David Armstrong, based on his thesis about the development of 'surveillance medicine'. ${ }^{22}$ The twentieth century, he argues, was a period of 'remapping' the spaces of medicine, transforming the role of the hospital and redesigning the differences between normal and pathological. In practical terms, this change resulted in the extrapolation of the hospital as the primary space of medicine. In this sense, screening would be a technical development of discipline and medical surveillance, thus aiming at disease and population control. ${ }^{23}$ The main success and dilemma posed by screening, Armstrong argues, was the incorporation of the principle of surveillance by the population, creating a moral responsibility for periodic examinations. $^{24}$

A third interpretive path to the history of screening concerns technological development and the process of incorporating new 'tools' into medical practice. According to Ilana

Luiz Antonio Teixeira, Tânia Salgado Pimenta and Gilberto Hochman (eds), História da Saúde no Brasil (São Paulo: Editora Hucitec, 2018), 101-44.

${ }^{17}$ INCA, Ministério da Saúde, Estimativa 2018: incidência de cancer no Brasil (Rio de Janeiro: INCA, 2018).

18 Ibid., 38.

${ }^{19}$ Migowski Arn et al., 'Diretrizes para detecção precoce do câncer de mama no Brasil. I - Métodos de elaboração', Cad. Saúde Pública, Rio de Janeiro, 34, 6 (2017), e00116317.

${ }^{20}$ Ibid.; see also INCA, O controle do câncer de mama no Brasil: trajetórias e controvérsias. Depoimentos para a história do controle do câncer no Brasil, vol. 3 (Rio de Janeiro: INCA, 2018).

${ }^{21}$ Weisz George, Chronic Disease in the Twentieth Century: A History (Baltimore: John Hopkins University Press, 2014).

22 David Armstrong, 'The Rise of Surveillance Medicine', Sociology of Health \& Illness, 17, 3 (1995), $393-404$.

23 David Armstrong, 'Screening: Mapping Medicine's Temporal Spaces', Sociology of Health and Illness, 34, 2 (2012), 177-93.

${ }^{24}$ Ibid., 189. 
Löwy, the development of diagnostic techniques effectively able to identify malignant tumours in the early stages has strengthened the early warning and early detection campaigns organised since the early twentieth century in the United States and Europe. ${ }^{25}$ The turning point, in the author's opinion, was the diffusion of the cytopathological examination for cervical cancer (Papanicolaou test), based on exfoliation, vaginal smears, and cytological analysis to identify altered cells. The generalisation of the test in the 1950s was the origin of the term 'screening' itself, used by gynaecologists Daniel McSweeney and Donald McKay. ${ }^{26}$ David Cantor also comments on the importance of 'Pap-smear' for expanding screening as a prevention technique, but he considers the introduction of mammography as a turning point in this history. ${ }^{27}$

We suggest that, in the Brazilian case, the historiographical approach centred on how technological development is appropriated and negotiated in health care systems offers additional insights to understanding breast cancer screening debates. Both health insurance and surveillance medicine approaches, although very interesting, did not have great expression in Brazilian history. This is mostly due to the path followed by cancer care, which focused on the tension between private and public sectors, and the negotiations on how technologies could be incorporated into daily practice and public health planning.

Our approach in this article is based on medical history and social studies of science, especially those that discuss the impact of new medical technologies in health care and clinical practice. In this sense, it is worth mentioning the work of Joel Howell about how the introduction of diagnostic tools in US hospitals in the early twentieth century changed daily experience of disease, as well as the organisation of hospital practice. ${ }^{28}$ These are similar to Charles Rosenberg's observations on how diagnostics was a multidimensional topic of interest in the twentieth century, since it changes the doctor-patient relationship, invokes specialisation, bureaucratisation and many other major processes in the medical profession. ${ }^{29}$ To our approach, it is also important to consider the accounts of Bruno Latour and Karin Knorr Cetina on the stabilisation of scientific facts and technological artefacts: despite disagreements between these authors, both sociologists argue that scientific activity is permeated by a variety of beliefs, interests and epistemic cultures, and that scientists need to articulate different actors to achieve their objectives. ${ }^{30}$

Such sociological approach supports our analyses about the role played by local contingencies in the incorporation of medical technology and the mobilisation of scientific knowledge for actors and institutions. As we discuss throughout the article, the incorporation of diagnostic and screening technologies in Brazil was as closely articulated to specific agendas of the medical profession and public health as much as to the limitations of the health system and social inequalities. Also, the social studies of science approach helps us to understand how actors of different social fields have

\footnotetext{
${ }^{25}$ Ilana Löwy, Preventive Strikes: Woman, Precancer and Prophylactic Surgery (Baltimore: John Hopkins University Press, 2010).

${ }^{26}$ Ibid., 128.

${ }^{27}$ Cantor David, 'Screening', in Mark Jackson (ed.), Routledge Encyclopedia of History of Disease (New York/London: Routledge, 2017).

28 Joel Howell, 'Technology in the hospital', in Transforming Patient Care in the Early Twentieth Century (Baltimore/London: The Johns Hopkins University Press, 1995).

${ }^{29}$ Charles Rosenberg, 'The Tyranny of Diagnosis: Specific Entities and Individual Experience', The Milbank Quarterly, 80, 2 (2002), 237-60.

${ }^{30}$ Bruno Latour, Ciência em Ação: como seguir cientistas e engenheiros sociedade afora (São Paulo: Ed. Unesp, 2000). Karin Knorr Cetina, Epistemic Cultures: How the Sciences make Knowledge (Cambridge, MA/London: Harvard University Press, 1999).
} 
mobilised their perspectives to negotiate breast cancer early detection and screening in Brazil, and how such dynamic imposes difficulties to the stabilisation of a consensus towards the subject.

We used several medical sources that discuss the topic in Brazil, mainly specialised leading oncology journals (e.g. Brazilian Journal of Cancerology, Oncology Archives, Brazilian Annals of Gynaecology and the Brazilian Journal of Gynaecology) published between 1950 and 2017, in addition to medical congress reports in the same period (Brazilian Mastology congresses, Brazilian Oncology campaigns), books and theses, institutional documents (consensus statement, internal dispatches, educational materials, decrees and laws) and oral testimonies of health professionals and patients' associations' representatives collected in the framework of 'The History of Cancer' project from the Oswaldo Cruz Foundation and Brazilian National Cancer Institute. ${ }^{31}$

In this sense, this article follows the trajectories of divergent approaches towards the control of breast cancer. It also investigates the dynamics of controversies and alignments among the main stakeholders (oncologists, surgeons, public health experts, health administrators, government officials, patients' associations and feminist groups) that led to the integration of technological innovations into Brazilian clinical and public health practices.

\section{The 'Cervical Model' and Beginnings of the Screening for Female Cancers in Brazil}

The history of screening for breast cancer in Brazil is inseparably intermingled with the one of screening for cervical malignancies. ${ }^{32}$ In Western Europe and North America, the organisation of screening for breast cancer was partly inspired by earlier campaigns of screening for cervical cancer. ${ }^{33}$ Still, the links between these two campaigns in Brazil were much more direct and immediate. In the 1940s, shortly after the development of the Pap smear, studies on the use of vaginal smear exams appeared in Brazil, while several institutions began to offer screening for cervical cancer, often based on a combination of the cervical smear with a colposcopy exam. At first, screening for cervical cancer was conducted in gynaecological outpatient clinics connected to medical schools or cancer hospitals. Later, some regions developed successful programmes of cervical cancer control, and groups of gynaecologists promoted discussions about the prevention and early diagnosis of cervical malignancies. ${ }^{34}$

The most important among the regional programmes for the screening for cervical tumours was developed in Campinas, a city located in the countryside of São Paulo state.

\footnotetext{
31 Oral testimonies were collected, transcribed and reviewed by researchers from 'The History of Cancer' project. Then they were submitted and approved by the National Committee of Ethics in Research (CONEP), with peer protocol number 51176915.4.0000.5241. Ten people - from among health professionals and patient's associations representatives - were interviewed concerning the topic of breast cancer screening in Brazil. Among them there were former directors of the National Cancer Institute, presidents of the Brazilian Radiology College, the Brazilian Surgical College and the Brazilian Mastology Society, as well as civil society entities such as the Avon Institute and the Federation of Institutions of Breast Cancer Patients (FEMAMA). All interviews were edited and published in a volume of an oral history series called Depoimentos para a história do controle do câncer no Brasil.

32 Ilana Löwy, 'Cancer, Women and Public Health: The History of Screening for Cervical Cancer', História, Ciências, Saúde-Manguinhos, 17, 1 (2010), 53-67.

33 Ibid.

${ }^{34}$ Luiz Teixeira, 'Ilana Löwy, Imperfect Tools for a Difficult Job: Colposcopy, "Colpocytology” and Screening for Cervical Cancer in Brazil’, Social Studies of Science, 41, 4 (2011), 585-608.
} 
This programme was implemented in 1965 at the region's medical school (which was the nucleus for the future University of Campinas). Established by gynaecologists José Aristodemo Pinotti and Luiz Carlos Zeferino, it was an innovative project, where public health experts proposed the integration of university research, service and professional training. ${ }^{35}$ It included screening for precursory lesions of cervical cancer, treatment of gynaecological pathologies encountered during the screening and a follow-up of the screened women. ${ }^{36}$

In the city of Rio de Janeiro, a cervical cancer prevention programme was developed by the Luiza Gomes de Lemos Research Centre of the Fundação Pioneiras Sociais (Social Pioneers Foundation). Inaugurated in 1957 to promote the control of cervical cancer, the Centre developed extensive interventions based on the active search of affected women, using mobile truck units for screening and gynaecological follow-ups in its outpatient clinics. ${ }^{37}$ In 1958, it also created a training school for cytology technicians.

The first programme for the mass detection of cervical cancer in the city of São Paulo was developed at the São Camilo Institute for the Prevention and Treatment of Gynaecological Cancer. Created in 1967, the Institute was directed by gynaecologist João Sampaio Góes Junior, and it was part of the São Camilo Philanthropic Hospital, which had a partnership with the state of São Paulo's Department of Health. ${ }^{38}$ The following year, thanks to the financial assistance of the São Paulo state government, Sampaio Góes founded the Brazilian Institute of Studies and Research in Obstetrics and Gynaecology (IBEPOG), a philanthropic organisation that initiated several campaigns of cervical cancer control in the state.

Sampaio Góes had close links with the state of São Paulo's political leaders of the time. Thanks to their support, he was able to mobilise public funds for philanthropic and private organisations, such as the São Camilo Hospital, the IBEPOG and, later, the Brazilian Cancer Control Institute (IBCC) - a private philanthropic institution that operated with sponsorship of public funds. ${ }^{39}$ These organisations' activities strengthened the principle of cancer control through the channelling of public funding to private activities. The success of Sampaio Góes' cancer-related activities and his political connections led to his appointment as the director of the National Cancer Division of the Ministry of Health in 1970 .

Campaigns for the early detection of cervical cancer indicated that it was possible to systematically examine healthy women to promote the prevention of cancer. The demonstration of this principle opened up new horizons for Brazilian public health. Cervical cancer became a model for the later implementation of breast cancer screening. Furthermore, the protagonists were the same.

\footnotetext{
${ }^{35}$ Luiz Teixeira, 'From Gynaecology Offices to Screening Campaigns: A Brief History of Cervical Cancer Prevention in Brazil', História, Ciências, Saúde-Manguinhos, 22 (2015), 221-39.

${ }^{36}$ Ibid.

${ }^{37}$ Rosana Temperini, 'Fundação das Pioneiras Sociaiis - contribuição inovadora para o Controle do Câncer do Colo do Útero no Brasil (1956-70)', Revista Brasileira de Cancerologia, 58, 3 (2012), 339-49.

${ }^{38}$ Fátima Capucci, Filosofia Sampaio Goes: Instituto Brasileiro de Controle do Câncer - IBCC 35 anos (São Paulo: Editora Activa Comunicação, 2003).

${ }^{39}$ Ibid.
} 


\section{Mammography in Brazil in the 1960s and 70s: Public and Private Health Care}

In the 1950s, physicians begun to systematically employ X-rays for early detection of breast cancer. The Uruguayan physician Raul Leborgne soon observed the importance of a better positioning of the breast and the need for its compression in order to improve the imaging quality during breast X-ray exams. Leborgne was the first physician to associate breast cancer with micro calcifications. By the end of the same decade, Robert Egan, a radiologist at the M.D. Anderson Cancer Centre in the US, noted that low voltage and high amperage could enhance the resolution of the X-ray image. His works, published in 1962, also demonstrated mammography's capacity to identify non-palpable tumours. At the same time, Gerald Dodd, another M.D. Anderson physician, developed a technique for locating non-palpable tumours, which increased the accuracy of excisional biopsy. In 1963, the Health Insurance Plan Trial (HIP Trial) in New York City, conducted by Phillip Strax, Louis Venet and Sam Shapiro, had shown that systematic clinical and radiological exams of breasts of healthy women reduced mortality from breast cancer. In the late 1960s and 70s, results of additional clinical trials strengthened the argument in favour of using mammographic screening for breast cancer control. ${ }^{40}$

In Brazil, the 1960s and 70s were marked by the establishment of a military dictatorship that lasted more than twenty years (1964-85), a development that had a great impact on medicine and public health. Consecutive military governments strengthened a welfare system based on a hospital-centred model. ${ }^{41}$ They also strongly promoted a liberal economic perspective on health care. Accordingly, they extended the use of the private health sector, where public hospitals and clinics hired or purchased services provided by private institutions. At the same time, military governments drastically reduced investment in public health activities, such as cancer prevention. ${ }^{42}$ The Brazilian military government was reducing its investment in preventive health care at the exact time when results of clinical trials were strengthening the argument in favour of mammographic screening for breast cancer. $^{43}$

During the 1960s and 70s, the Brazilian Society of Mammary Pathology, which had been created in 1959 following a meeting of surgeons from the National Cancer Institute (INCA) with gynaecologists and surgeons from state institutes for cancer control, played an important role in discussions about diagnosis and treatment of breast cancer. The Society's congresses brought together experts on breast diseases and debated topics such as surgical treatment of breast malignancies, regulation of medical practice and screening for cancer. The first mammogram machine used in Brazil was imported in 1970 by Sampaio Góes for the IBEPOG. In 1972, the Luiza Gomes de Lemos Research Centre (CPLGL) in Rio de Janeiro, acquired a mammograph and offered mammographic screening for breast cancer to women who attended their gynaecological centre. In 1974 the CPLGL employed a mobile mammography unit to conduct breast cancer screening campaigns in several districts of Rio de Janeiro state. The CPLGL also organised public lectures about the importance of monthly breast self-examination and mammographic screening

\footnotetext{
${ }^{40}$ Barron Lerner, The Breast Cancer Wars: Hope, Fear, and the Pursuit of a Cure in Twentieth-Century America (New York: Oxford University Press, 2001), 202-15.

${ }^{41}$ Sarah Escorel and Luiz Teixeira, 'História das políticas de saúde no Brasil de 1822 a 1963: do império ao desenvolvimentismo populista', in Ligia Giavonella et al. (ed.), Políticas e Sistemas de Saúde no Brasil (Rio de Janeiro: Editora Fiocruz, 2008).

42 Teixeira and Fonseca, op. cit. (note 6).

${ }^{43}$ Lerner op. cit. (note 24).
} 
and created a system to register women who used the Centre's services, which would provide data for the CPLGL and favoured the follow-up of patients. CPLGL's educational activities highlighted the importance of mammographic screening for all women over the age of $40 .{ }^{44}$

In 1973, a partnership between the Brazilian Institute of Cancer Control, the São Paulo State Department of Health and the São Caetano Department of Hygiene developed a pilot programme of screening for breast and cervical cancers in the city of São Caetano in the state of São Paulo. The programme's protocol provided physical examination performed by non-physicians; clinical examination in selected cases; and mammography, needle biopsy and cytological investigation of diagnosed anomalies. ${ }^{45}$

The São Caetano and Rio de Janeiro initiatives reflected a steady increase in government concerns about cancer in Brazil. In 1973, following the example of US President Richard Nixon, who launched the Cancer Act in 1971, the Brazilian president/general at the time, Emílio Garrastazu Médici, publicly announced on national radio and television chains the implementation of a large-scale governmental anti-cancer programme. This programme, Médici explained, would promote the purchase of advanced equipment by specialised hospitals, create state and regional anti-cancer centres with several levels of complexity and train specialised health care workers. ${ }^{46}$ In order to make this a feasible proposal, the Ministry of Health created the National Cancer Control Program (PNCC), headed by Sampaio Góes. The programme's aim was to coordinate cancer-related activities nationwide and integrate public and private sector interventions. In practice, probably because of the training of its director, this programme focused almost exclusively on the prevention of female cancers. ${ }^{47}$

In line with the policy of the military government, which prioritised the state purchase of private sector health services, ${ }^{48}$ PNCC promoted state-funded reimbursement of all cancerrelated procedures performed in private hospitals and laboratories. This programme also stipulated that private institutions that had ties with the National Cancer Division (DNC) of the Ministry of Health could receive equipment for diagnosis and treatment of cancer on a loan-for-use basis. Mammographs and other instruments bought with public funds were either handed over to the state public network or, frequently, to private hospitals and clinics. ${ }^{49}$ PNCC's distribution of equipment purchased by the state among private facilities reinforced the position of these facilities and led in fine to a strong state dependency on privately owned equipment and services.

In the 1970 s and 80 s the private sector became a key arena in the elaboration of cancer control policies, a development that had dire consequences for public health-oriented approaches in this domain. ${ }^{50}$ An increase in the number of mammography machines, dedicated to diagnosis and concentrated mainly in private hospitals and clinics, hindered

\footnotetext{
${ }^{44}$ Fundação das Pioneiras Sociais, Relatório do Centro de Pesquisas Luiza Gomes de Lemos (Rio de Janeiro: Fundação das Pioneiras Sociais, 1974).

45 Sampaio Goes et al., 'Programa de detecção em massa do câncer da mama - I.B.C.C - 1973/1976', Anais do IV Congresso Brasileiro de Mastologia (Campinas: Sociedade Brasileira de Mastologia, 1977).

${ }^{46}$ Capucci, op. cit. (note 38).

${ }^{47}$ Regina Bodstein (ed.), História e Saúde Pública: a política de controle do câncer no Brasil (Rio de Janeiro: PEC/ENSP, 1987).

${ }^{48}$ Silvia Gerschman, Maria Santos and O. Sistema, 'Único de Saúde como desdobramento das políticas de saúde do século XX', Revista Brasileira de Ciências Sociais, (2006), 177-90.

49 Teixera and Fonseca op. cit. (note 6).

${ }^{50}$ Luiz Teixeira, Marco Porto and Claudio Noronha, O Câncer no Brasil, Passado e Presente (Rio de Janeiro: Outras Letras, 2012).
} 
the possibilities of broader and coordinated actions to control cancer. It also strengthened the demand, originated in the private health sector, for an increased use of mammographic screening. This demand frequently clashed with ideas developed in the public sector.

Discussions among specialists in the private sector were focused on the best use of thermography, mammography, cytology and ultrasonography for the early diagnosis of breast cancer. Mammography was seen as a technology that could be more successful in the following decades. ${ }^{51}$ However, in the 1970s public health debates about screening for breast cancer were focused on breast self-examinations and clinical breast examinations. In 1974, the National Cancer Division created the Breast Cancer Control Operative Group. This group recommended clinical breast examination every six months, or every four months in high-risk patients. ${ }^{52}$ Three years later, studies presented at the Fourth Congress of the Brazilian Society of Mastology advocated mammographic screening for breast malignancies. At the same time they stated that, although the technique was efficient, the costs made it less appropriate for Brazil, compared to self- and clinical examinations. ${ }^{53}$ This view was challenged during the 1980s and 90s.

\section{Controversies on Breast Cancer Control in Brazil in the 1980s and 90s}

In the mid-1980s, Brazil was on an ongoing path to democracy after more than twenty years of dictatorship. Numerous civil society organisations flourished, making specific demands on the state, including in the area of health care. ${ }^{54}$ One of such demands was the elaboration of a policy surrounding the promotion of women's health that did not reduce the issue to a simple surveillance of their reproductive functions. The concept of a global approach to women's health originated in the same institutional nucleus of the University of Campinas (UNICAMP) that had organised the first screening campaigns for both cervical and breast cancers. This group, led by José Aristodemo Pinotti and Luiz Carlos Zeferino, gathered physicians from the Centre for Integrated Women's Health Care (CAISM) at the University of Campinas and from the Centre for Women's Health at the University of São Paulo (USP). ${ }^{55}$ The group played a major role in the formulation of what would become the national Program of Integrated Attention to Women's Health (PAISM), promulgated by the Brazilian Ministry of Health, in 1984. This programme proposed educational, preventive, diagnostic, therapeutic and rehabilitation interventions on a broad range of issues linked with women's health. Among these issues were prenatal, childbirth and post-partum care; treatment of gynaecological pathologies and menopause symptoms; family planning; control of sexually transmitted diseases; and prevention and treatment of female cancers. ${ }^{56}$ Researchers from USP and UNICAMP, inspired by public health experts' ideas, advocated for a large-scale dissemination of low-tech approaches to the improvement of women's health, while also proposing to integrate such approaches into primary health care interventions. ${ }^{57}$

51 Arquivos de Oncologia, 'Mesa redonda: Avaliação dos métodos propedêuticos na prevenção e diagnóstico precoce do câncer de mama', Arquivos de Oncologia, XVII, 1 (1976).

52 Simão Rostein, 'Diagnóstico precoce do câncer mamário', Ginecologia Brasileira, III, 1 (1976), 63-8.

53 Lair Barbosa, 'Valor do Exame Clínico e da Auto-palpação', Anais do IV Congresso Brasileiro de Mastologia (Campinas: Sociedade Brasileira de Mastologia, 1977).

${ }^{54}$ Nisia Lima (ed.), Saúde e democracia: história e perspectivas do SUS (Rio de Janeiro: Editora Fiocruz, 2005).

55 C. Rosa, Caism: a história de sua implantação (Campinas: Universidade Estadual de Campinas, 2002).

56 Ibid.

${ }^{57}$ Ministério da Saúde, Assistência integral à saúde da mulher: bases da ação programática (Brasília: Ministério da Saúde, 1984). 
The specialists at UNICAMP and USP argued that the large increase in incidences of breast cancer in Brazil transformed this malignancy into a major public health problem. ${ }^{58}$ It was essential to implement a large-scale screening programme for breast tumours while avoiding the high costs of such screening, a characteristic feature in developed countries. Accordingly, they recommended giving priority to clinical- and self- breast examinations - lower cost interventions seen as better adapted to reduction of mortality rates in underdeveloped regions. ${ }^{59}$

Another group of specialists that advocated similar ideas about breast cancer control was based at INCA. After an institutional crisis in the 1970s that reduced INCA's actions to the areas of education and care, the Institute reinforced its structure in the 1980s and returned to activities in cancer research and prevention. At the same time, the Pan American Health Organization (PAHO) intensified its activities in partnerships for cancer control in the region, financing projects, training human resources and proposing recommendations that fit regional specificities. ${ }^{60}$

In 1985, INCA organised a seminar on gynaecological cancers, with the participation of leading national and international actors. At the event, David Boyes, director of the Cancer Control Agency of British Columbia (Canada), discussed screening for cancer in developing countries. Based on the Canadian experience with the control of cervical cancer, Boyes sought a broader reflection on the possibilities of implementing screening programmes in different contexts. A primary point raised by him, and still somewhat unclear in the vocabulary of Brazilian cancer medicine, was the distinction between diagnosis and screening. The latter, Boyes claimed, was about public health and therefore 'to be effective must be made on wide basis and in the cheapest way possible'. ${ }^{61}$ For some locations, such as breasts, Boyes believed that there still lacked scientific evidence of the effectiveness of screening, which demanded more clinical trials. He argued that the main concern in these countries should be the improvement of living conditions of the population, not the purchase of advanced and expensive diagnostic technologies: ${ }^{62}$

Before thinking about any cancer control program in underdeveloped countries, minimum conditions must be created for the well-being and health of their populations: drinking water, hygiene and nutritious food are indispensable factors for future organization and execution of programs effective. Cancer is a disease characteristic of older people; we must give people the conditions to reach old age so that we can fight the carcinomas that develop. ${ }^{63}$

Boyes' speech was provocative to the discussion among Brazilian participants, who relied on the regional experiences of cervical cancer to talk about the feasibility of screening in the country. Estela de Aquino, head of INCA's Division of Epidemiology at the time, presented a general report on the actions of control of cervical tumours in the country, highlighting the existence of programmes limited to specialised institutions in

\footnotetext{
58 Although cancer registry in Brazil was far from precise in the 1980s, first reports of breast cancer incidence indicated this type of tumour as the second most common among women, with over 10000 notified cases, below only cervical cancer. See Rodolfo Brumini, Câncer no Brasil: dados histopatológicos (Brasília: Ministério da Saúde, 1982).

${ }^{59}$ Luiz Zeferino, 'Programa e Avaliação das atividades de controle: a experiência de Campinas', Revista Brasileira de Cancerologia, 31, 3 (1985), 205-10.

${ }^{60}$ Nildo Aguiar, 'Institutos de Câncer e Equipes de Saúde', Revista Brasileira de Cancerologia, 29, 4 (1983), 40-2.

${ }^{61}$ David Boyes, 'A experiência mundial no controle do câncer cérvico-uterino e de mama tendência e problemas', Revista Brasileira de Cancerologia, 31, 3 (1985), 179-84.

${ }^{62}$ Ibid., 183. Translated from Portuguese.

${ }^{63}$ Ibid., 184. Translated from Portuguese.
} 
several states, mainly in Southern Brazil. ${ }^{64}$ The advance towards a national programme, according to the epidemiologist, demanded the incorporation of the cytopathological examination into the Brazilian clinical routine, which involved negotiations with health care services and the daily practice by the medical profession. In addition, Aquino commented on the difficulty of capillary work, both for the underutilisation of the state health departments and for the lack of a greater structural integration.

The current situation of the State Health Departments is still characterized by underutilization of physical and human resources in the laboratory area. Most Departments do not have a structure adequate to the development of the activity. Regarding the questionnaires, it was observed that the regional information systems are not adequate to respond to these evaluation mechanisms. Problems such as slowness in submitting questionnaires and doubts as to the veracity of their information were frequent. Failure to refer to the specific programming and standardization of procedures by most Secretariats indicates that these activities appear to be developing based on spontaneous demand, with no subsequent evaluation of the outcome of their development. ${ }^{65}$

Discussions on the adequacy of screening in developing countries is only a piece of a larger puzzle in social interpretations of cancer in Brazil. Since the 1960s, when oncologists from North-eastern Brazil started to discuss cancer incidence in that area along with its connection with specific conditions of 'underdeveloped' regions, traditional views of neoplasms as a 'sign of civilization' were gradually confronted by debates towards the relationship between socioeconomic development and health. ${ }^{66}$ In this scenario, socioeconomic disparities among Brazilian regions became a relevant topic to decision and policymaking in public health. Hence, it would not be possible to plan nationwide actions without taking inequalities into account. ${ }^{67}$ Therefore, any screening programme to be a nationwide one - had to deal with the difficulty of implementing health policies in the whole of Brazil's territory.

In the late 1980s, the establishment of a Brazilian national health system, henceforth known as the Unified Health System (SUS), radically modified the health care arena. This occurred in spite of the fact that the public system continued to coexist with a private sector that provided services to twenty-five per cent of the Brazilian population, and to the quasi totality of middle- and upper-class Brazilians. The foundation of SUS - based on the principle of 'universal right to health' - redefined strategies in health care. It also opened the way for the increased participation of society members, be they professionals or lay persons, in decisions about health policies. ${ }^{68}$ However, the private sector kept its major role in health policy. Moreover, oncology experts frequently oscillated between the public and private health care sectors, blurring their different interests and motivations.

With the creation of SUS, INCA became officially responsible for defining a cancer policy in Brazil. Its new status expanded its capacity to propose guidelines for cancer control. In the 1980s these guidelines followed the main opinion of public health experts, who advocated the need to adapt Brazilian screening programmes to the multiple national realities. ${ }^{69}$ Thus, in 1985, INCA's seminar recommended screening for breast cancer

${ }^{64}$ Estela de Aquino, 'Avaliação das Ações de Controle do Câncer no Brasil', Revista Brasileira de Cancerologia, 31, 3 (1985), 185-90.

65 Ibid., 187-8.

${ }^{66}$ Luiz Alves, Araújo Neto and Luiz Antonio Teixeira, 'From Disease of Civilization to Public Health Problem: Cancer, Society and Medical Profession in the 20th Century', Bol. Mus. Para. Emílio Goeldi. Ciênc. hum., [online] 12, 1 (2017), 173-88.

${ }^{67}$ C.H. Wood and J.A.M. de Carvalho, The Demography of Inequality in Brazil, 2nd edn, Cambridge Latin American Studies (Cambridge: Cambridge University Press, 2009).

${ }^{68}$ Lima,, op. cit (note 54).

${ }^{69}$ Eduardo Faerstein, 'Screening em câncer', Revista Brasileira de Cancerologia, 32, 2 (1986), 133-5. 
through clinical examination and breast self-examination. ${ }^{70}$ From 1987 onwards, INCA, in partnership with state and municipal health departments and Pro-Onco (a programme created by the federal government to promote the prevention and early diagnosis of cancer), started large-scale educational campaigns. Initially, these campaigns continued to advocate low-tech approaches to screening for breast cancer; INCA's position was, however, challenged in the 1990s.

In the 1990s, a period of growing influence of evidence-based medicine and the publication of results from randomised clinical trials in Canada and Sweden strengthened the position of advocates for mammographic screening. ${ }^{71}$ The creation of SUS democratised debates on health care in Brazil, but at the same time increased possibilities to mobilise lobbies and advance agendas of specific interest groups. In the 1990s, new groups of professional and lay stakeholders joined the debate on screening for breast malignancies. Until then, discussions on the use of mammography as a screening tool were limited to medical experts, especially those linked with INCA. In the closing years of the twentieth century, breast cancer prevention gained a much greater public visibility, mainly due to the emergence of the first associations of breast cancer patients and the growing importance of the Brazilian Mastology Society. Although for different reasons, both groups advocated for health care-users increased access to new medical technologies.

Brazilian specialists who favoured a public health-based approach recognised that mammographic screening could detect early cancers. However, at the same time, they believed that decisions about the implementation of a large-scale screening programme should consider its cost-benefit ratio. In a developing country such as Brazil, they argued, public health funding limitations could not be ignored in planning populationbased programmes, especially those that involved high cost technologies such as mammography. ${ }^{72}$ In the 1980 s, the Union for International Cancer Control (UICC) recommended carrying out mammographic screening every one to two years for women between the ages of fifty and seventy ${ }^{73}$ Nevertheless, many Brazilian public health experts continued to assert that the costs of implementation of such recommendations in Brazil were too high, mainly because of important regional differences in access to this diagnostic technology. Mammographic screening, they argued, had (probably) high efficacy, but it had low effectiveness in Brazil. ${ }^{74}$

On the one hand, following the guidelines of the PAHO, in 1993 INCA recommended screening for breast cancer based on self-examination and clinical breast examination. On the other hand, INCA's statement did not oppose mammographic screening, but subordinated its use to 'medical criteria', a vague statement that in practice gave free rein to specialists.

In the 1990s, patients' associations became enthusiastic promoters of mammographic screening. Until then, the main goal of these associations (known in Brazil as 'Leagues'), was the collection of funds for the expansion of cancer research and treatment. ${ }^{75}$ The

\footnotetext{
${ }^{70}$ Revista Brasileira de Cancerologia, 'Seminário sobre controle do câncer cérvico-uterino e de mama. Relatório Final', Revista Brasileira de Cancerologia, 31, 3 (1985), 237-9.

${ }^{71} \mathrm{P}$. Gøtzsche and K. Jorgensen, op. cit. (note 4).

72 José Pinotti et al., 'Rastreamento em países em desenvolvimento', in José Pinotti e Umberto Veronesi (ed.), Câncer de mama (São Paulo: Editora Cultrix, 1992).

${ }^{73}$ E. Lopes, E. Abreu and M. Gadelha, 'Detecção do Câncer de mama: atualização e recomendações', Revista Brasileira de Cancerologia, 39, 1 (1993), 21-6.

${ }^{74}$ Ibid.

75 Teixeira, Porto and Noronha op. cit. (note 50).
} 
combined effect of the new health system's increased openness to the demands of civil society, the existence of expensive, less accessible technologies for cancer diagnosis and the influence of the position adopted by US patient organisations had transformed Brazilian associations into advocacy forums for mammographic screening. During the same decade, the available data strongly supported the claim that mammographic screening reduced breast cancer mortality. ${ }^{76}$ At that same time, debates towards the recommendation on screening mammography took place in the US involving the NCI, the US Preventive Task Force and medical societies such as the American College of Radiology. The main controversy was about the age at which screening should begin: the NCI recommended starting mammographic screening at the age of fifty, while radiologists and patients' associations believed that screening should start at the age of forty. ${ }^{77}$

Brazilian patients' associations argued that the cost-benefit ratio of mammographic screening should be viewed as less important than the screening's capacity to save lives. Accordingly, one of their main demands was increased access to mammographic screening for all Brazilian women, and the reduction of the initial age of screening from fifty to forty. $^{78}$

Initiatives in favour of mammographic screening were also supported by numerous professional organisations, such as Brazil's most important breast cancer organisation, Instituto da Mama (Breast Institute) founded in 1993. Instituto da Mama initially sought to provide multi-professional support to patients, including psychologists, nurses and medical students, and to inform them about cancer treatment. Its director, the mastologist Maira Caleffi, closely collaborated with the American Cancer Society (ACS). Instituto da Mama initiated actions to raise women's awareness about the importance of the early detection of breast cancer. ${ }^{79}$ It rapidly became the leader of social mobilisation in favour of an extensive access to mammographic screening.

Other important actors in 1990s' debates on mammographic screening were professional organisations, such as the Brazilian Society of Mastology (previously known as the Society of Mammary Pathology), the Brazilian Society of Gynaecology and Obstetrics and the Brazilian College of Radiology. While the main concern of health experts was the effectiveness of mammographic screening, ${ }^{80}$ and that of patients' associations was the reduction of cancer mortality, medical societies aspired, above all, to valorise their members' expert knowledge. Members of the Gynaecology and Obstetrics Society, the professional group which, from the beginning of the twentieth century, dealt with female cancers, sought to legitimate and consolidate their status as the leading experts in this domain. ${ }^{81}$ Radiologists, medical specialists defined through the use of a specific technology, unsurprisingly gave strong support to a widespread diffusion of mammographic (that is, radiological) screening. ${ }^{82}$ At the same time, radiologists stressed

\footnotetext{
${ }^{76}$ P. Gøtzsche and K. Jorgensen, op. cit. (note 4).

77 S. Fletcher, 'Whiter Scientific Deliberation in Health Policy Recommendations? Alice in the Wonderland of Breast Cancer Screening', The New England Journal of Medicine, 336, 16 (1997), 1180-3.

${ }^{78}$ See interview with leading advocacy Maíra Caleffi in: INCA, Ministério da Saúde, O Controle do Câncer de Mama no Brasil: Trajetórias e Controvérsias (Rio de Janeiro: INCA, 2018).

${ }^{79}$ Ibid

${ }^{80}$ Lopes, Abreu and Gadelha, op. cit. (note 73).

${ }^{81}$ Ana Martins, Visões do Feminino. A medicina da mulher nos séculos XIX e XX (Rio de Janeiro: Editora Fiocruz, 2004).

${ }^{82}$ Bernick Pasveer, 'Knowledge of Shadows: The Introduction of X-ray Images in Medicine', Sociology of Health and Ilness, 11, 4 (1989), 360-81.
} 
that the efficacy of mammographic screening depended on the quality of radiological exams. It was therefore crucial to train high-level specialists in this area. In 1993, the Brazilian College of Radiology, together with the National Nuclear Energy Commission, created the Mammography Quality Certification Program. The programme improved the quality of the professional certification examination; it also confirmed the central place of radiology in the control of the practice of mammography. ${ }^{83}$

The position of mastologists - surgeons specialising in pathologies of the breast evolved with time. In the early 1990s, mastology was a recently configured specialty, still in the process of gaining professional acceptance. Unlike radiology, mastology is a surgical specialism, and surgeons specialised in pathologies of the breast were proud of their ability to diagnose breast cancer during a clinical examination. Moreover, the majority of the members of the Brazilian Society of Mastology (SBM) were, initially, surgeons associated with INCA. In the early to mid-1990s, SBM shared INCA's vision of breast cancer screening, and advocated giving priority to self-examinations and clinical examinations. ${ }^{84}$ However, when SBM became institutionalised and attracted new members, the Society became predominantly composed of physicians from the private health sector. Accordingly, it aligned its position with the interests of that sector and opposed INCA's position.

\section{Breast Cancer Screening in Brazil in the Twenty-first Century: Living with Contradictions}

Conflict lines drawn in the 1990s between public health experts associated with INCA on the one hand, and professional associations of physicians and patients' organisations on the other hand, continue to shape breast cancer screening in twenty-first century Brazil. Beginning in the late 1980s, INCA was responsible for defining public policies and guidelines for cancer control in Brazil, but until the late 1990s the Institute limited its direct intervention in the domain of breast cancer control to its education campaigns. ${ }^{85}$ In 1998, INCA and the Ministry of Health organised the joint workshop 'Breast cancer - perspectives of control' ${ }^{86}$ Representatives of numerous groups of stakeholders participated in this workshop, which was concluded with a decision to create a national breast cancer screening module. This module was to be merged with the newly created national cervical cancer screening campaign Viva Mulher (Long Live Women). In practice, however, the Viva Mulher programme continued to emphasise cervical cancer, and the scope of its breast cancer-oriented activities remained restricted. ${ }^{87}$

In 2003, the Ministry of Health and INCA, with the support of the Brazilian Society of Mastology, organised a new workshop to discuss and approve recommendations regarding breast cancer control. This workshop gathered experts from different areas of the Ministry, health care administrators, researchers and representatives of scientific societies, feminist organisations and patient associations. ${ }^{88}$ The goal was to produce a consensus document

\footnotetext{
83 João Peixoto, 'Qualidade em mamografia', Revista Brasileira de Cancerologia, 39, 2 (1993), 127-33.

${ }^{84}$ Sociedade Brasileira de Mastologia, Boletim da SBM vol. 7, 2 (Agosto, 1995), 40.

${ }^{85}$ Porto, Teixeira and Silva, op. cit. (note 10).

${ }^{86}$ INCA, Viva Mulher, Câncer do colo do útero: informações técnico-gerenciais e ações desenvolvidas (Rio de Janeiro: INCA, 2002).

${ }^{87} \mathrm{Ibid}$.

${ }^{88}$ See interview with Maira Caleffi, in: INCA, Ministério da Saúde, O Controle do Câncer de Mama no Brasil: Trajetórias e Controvérsias (Rio de Janeiro: INCA, 2018).
} 
that would standardise guidelines on breast cancer screening and diagnosis. During this meeting, participating groups attempted to consolidate their representative position and the legitimacy of their respective standpoints. Thus, in order to strengthen its positions vis-à-vis experts and patient associations, INCA sought to align itself with the leaders of the feminist movement, in particular the National Feminist Network on Sexual Rights and Reproductive Rights, whose main leader, Maria do Espírito Santo, later became part of the Institute's staff. Nowadays, Espírito Santo works at the Division of Early Detection and Support to Cancer Care at INCA, articulating local health departments and social movements to national policies related to female cancers.

INCA's experts maintained a reserved opinion about extending frequency and age to start mammographic screening. ${ }^{89}$ They closely monitored World Health Organization (WHO) pronouncements that did not support such screening in developing countries; they also continued to oppose the advancement of screening to the starting age of forty. INCA's experts viewed the aspiration to scale up the use of mammography as a result of collusion between the interests of medical sub-specialties, patients' associations and the health industry. ${ }^{90}$ The alignment with women's associations by INCA temporarily shifted the balance in favour of a more moderate use of mammography. ${ }^{91}$ The consensus document issued at the 2003 workshop recommended screening by annual clinical breast examination for women aged between forty and forty-nine, and a mammographic examination every two years for women aged between fifty and sixty-nine. For women classified as being at 'high risk' of breast malignancies, INCA recommended starting annual clinical breast examinations and mammograms at the age of thirty-five. The consensus document also emphasised the need to guarantee access to diagnosis, treatment and follow-ups for all women whose clinical examinations produced abnormal results. In the wake of the document's publication, the Ministry of Health issued new guidelines that stressed the importance of the control of breast cancer. ${ }^{92}$

Despite its name, the 2003 consensus document did not put an end to the controversies surrounding breast cancer prevention in Brazil. The principle of screening every two years instead of every year for women aged fifty to sixty-nine ${ }^{93}$ was rejected by several patient organisations and medical societies, which continued to advocate annual mammographic screening for women between the ages of forty and seventy. An article published in 2003 in the Brazilian Journal of Mastology argued that the consensus document's recommendations were guided by financial considerations and were not grounded in scientific facts. ${ }^{94}$ For the authors of the 2003 article, 'recommendations on mammographic screening should be based solely on the benefits and risks applicable to each woman, and policy considerations should not affect the decisions of medical societies when formulating consensus protocols'. ${ }^{95}$

The creation of the Brazilian Federation of Philanthropic Breast Health Institutions (FEMAMA) in 2006 led to the intensification of patient associations' demands in two

\footnotetext{
${ }^{89}$ See interview with Maria Inês Gadelha, ibid.

90 Ibid.

91 Porto, Teixeira and Silva op. cit (note 10).

92 Ibid

93 Ministério da Saúde, Controle de Câncer de Mama: documento de consenso (Brasília: Ministério da Saúde, 2004).

94 S. Bauab and V. Aguillar, 'Rastreamento mamográfico para detecção precoce do câncer de mama', Revista Brasileira de Mastologia, 13, 2 (2003), 82-9.

95 Ibid.
} 
areas: reduction of the age of initial mammographic screening, and a more comprehensive coverage of its costs. In 2010, FEMAMA, together with the Brazilian Society of Mastology, launched an official document that recommended an annual mammographic screening for all women, starting at the age of forty. ${ }^{96}$ Two years later, a document jointly published by the Brazilian College of Radiology, the Brazilian Society of Mastology and the Brazilian Federation of Gynaecology and Obstetrics Associations made similar recommendations.

The publication of the 2003 consensus document was followed by contradictory legislative initiatives. Their incoherence mirrors the complexity of the relationship between public and private health care sectors in Brazil. Nevertheless, in 2008, Brazil's National Congress enacted Law No. 11 664, which ensured a 'mammographic examination for all women from the age of forty onwards' ${ }^{97}$ By contrast, in 2015 the Ministry of Health published new guidelines for the early detection of breast cancer in Brazil, which redirected the focus of public health to early detection and recommended that women between fifty and sixty-nine seek regular examination for breast cancers every second year after the initial screening. ${ }^{98}$ A 2015 Ministry of Health ordinance similarly affirmed that early detection in the public sector should follow the age group defined in the consensus of 2004, i.e. fifty to sixty-nine years, with an examination every second year. The latter ordinance generated a paradoxical situation, since it openly contradicted a law adopted by the highest Brazilian legislative body.

In sum, differences in opinions on mammographic screening in Brazil were shaped by complex interactions between stakeholders' interests, beliefs, perspectives and values. In Brazil, the key stakeholders were medical societies, patient associations and public health experts. The persisting difficulty in reconciling their respective points of view produced ambiguous proposals and inconsistent recommendations.

\section{Conclusion}

In the last fifty years, the transformation of cancer into a public health issue, coupled with the earlier development of screening for cervical malignancies, favoured the emergence of different models of breast cancer control in Brazil. The increase in the number of mammograph machines in the private sector, and especially in specialists' consulting rooms, fostered interest in the new technology. At that point, different actors - representatives of private and philanthropic medical institutions, specialised medical societies and patient associations - boosted the demand for the use of mammographic screening.

In sum, three distinct views of mammographic screening have emerged in Brazil between the 1960s and 2000s. Many public health experts followed the guidelines of international agencies (PAHO/WHO), affirming that it was not appropriate to implement government-sponsored mass screening programmes in a country with economic inequality and limited access to health services. Medical societies - usually supported by representatives of private medicine - grounded their support of mammographic screening

\footnotetext{
${ }^{96}$ Federação Brasileira de Instituições Filantrópicas de Apoio à Saúde da Mama - Femama. Documento de Posição da FEMAMA para o diagnóstico precoce do câncer de mama (Rio de Janeiro: Federação Brasileira de Instituições Filantrópicas de Apoio à Saúde da Mama - Femama, 2010).

97 Brasil, op. cit. (note 1).

98 Ministério da Saúde, Diretrizes para a detecção precoce do câncer de mama no Brasil (Brasília: Ministério da Saúde, 2015).
} 
in the technological efficacy of this approach in reducing mortality from breast cancer. Their position reflected the need to consolidate the professional standing of the medical specialties - mastology, radiology, gynaecology- involved in diagnosis and treatment of breast malignancies. Finally, patient associations followed the example of US organisations, such as the ACS, and advocated the broadening of access to mammography through the reduction of the minimum age for screening and a greater frequency of tests.

A persisting disagreement between stakeholders' standpoints has led to the absence of an agreement on the rules that should govern mammographic screening in Brazil. The influence of the private health care sector in defining public health actions in Brazil, in addition to the government's inability to regulate this sector, has contributed to this impasse. In fact, Brazil has never experienced a nationwide breast cancer screening programme. Although the Viva Mulher programme (1998-2005) presumed actions in that area, only cervical cancer prevention was achieved.

Controversies about breast cancer screening are still going on in the Brazilian health field, mostly regarding the coverage of public health care to mammography. INCA's position on the topic, however, has changed in the past decade. The latest guidelines on breast cancer control shifted the focus from screening to early detection, arguing - mainly by advocacy groups and medical societies - that screening is overestimated and does not have its effectiveness confirmed by systematic reviews. ${ }^{99}$ In addition, INCA's working group adopted a new method to formulate the guidelines, based only on systematic reviews (following the Oxford Centre for Evidence Based Medicine procedures) and not establishing discussions with medical societies and advocacy groups. Even though INCA's experts recognise the mentioned limitations of new methods, ${ }^{100}$ new procedures and positions on breast cancer control indicate that screening controversies are far from being solved. In sum, new guidelines are favoured to opportunistic screening between ages fifty and seventy; against teaching of self-examination as a screening tool.

Currently, Brazil has two distinct breast cancer prevention programmes. Middle-class women who have private health insurance plans have annual mammograms from the age of forty onwards. Poor women who depend on public health services can, in principle, have a screening mammogram every second year between the ages of fifty and seventy. In practice, however, their access to such screenings depends on the structure of health services in the region where they live, and many women not only have no possibility to be screened regularly, but also face difficulties in obtaining a mammographic diagnosis of breast anomalies detected during a clinical examination. ${ }^{101}$

Debates about screening for breast cancer in Brazil highlight a persisting difficulty in the relationship of society with technoscience: how to manage the tensions between actors with different interests when faced with uncertain scientific evidence. These discussions are also dominated by mutual accusations of bad faith. ${ }^{102}$ Medical specialists' associations and patient organisations link official recommendations to start screening for breast cancer at the age of fifty, and subsequent screening every two years, to the government's (presumed) choice to save money rather than to save women's lives. These groups

\footnotetext{
${ }^{99}$ Arn Migowiski et al., 'Diretrizes para detecção precoce do câncer de mama no Brasil. II - Novas recomendações nacionais, principais evidências e controvérsias', Cadernos de Saúde Pública, 34, 6 (2018), 1-13. 100 Ibid., 12

101 G. Oliveira et al., 'Condicionantes socioeconômicos e geográficos do acesso à mamografia no Brasil, 20032008', Ciência e Saúde Coletiva, 16, 9 (2011), 3649-64.

102 INCA, op. cit. (note 63).
} 
hold strong sway over society through efficient advertising campaigns, notably the one conducted during 'Pink October'. Public health experts thus are often on the defensive and unable to utilise arguments about the dangers of the overdiagnosis and overtreatment of breast malignancies. ${ }^{103}$ These health experts claim that their opponents' views reflect their (presumed) subservience to the interests of big biomedical corporations. Nevertheless, a few experts have discussed the risks of breast mammography screenings and the possible inadequacy of this strategy in Brazilian public health. ${ }^{104}$

103 Ibid.

${ }^{104}$ C. Tesser and T. D’Ávila, 'Por que reconsiderar a indicação do rastreamento do câncer de mama?', Cad. De Saúde Pública, 32, 5 (2016), 1-12. 